\title{
Overexpression of murine small heat shock protein HSP25 interferes with chondrocyte differentiation and decreases cell adhesion
}

\author{
N Favet ${ }^{1,3}$, O Duverger ${ }^{\star, 1,3}$, M-T Loones ${ }^{1}$, A Poliard ${ }^{2}$, \\ $O$ Kellermann ${ }^{2}$ and $M$ Morange ${ }^{1}$ \\ ${ }^{1}$ Unité de Génétique Moléculaire. Ecole Normale Supérieure. 46, rue d’UIm. \\ 75230 Paris. Cedex 05. France \\ 2 Laboratoire de Différenciation Cellulaire. Unité de Génétique Somatique. \\ Institut Pasteur. 25, rue du Dr. Roux. 75724 Paris. Cedex 15. France \\ ${ }^{3} \mathrm{~N}$ Favet and 0 Duverger contributed equally to this work \\ * Corresponding author: Olivier Duverger, Unité de Génétique Moléculaire. \\ Ecole Normale Supérieure. 46, rue d'Ulm. 75230 Paris. Cedex 05. France. \\ Tel: (33) 14432 39 45; Fax: (33) 1443239 41; E-mail: duverger@horus.ens.fr
}

Received 2.8.00; revised 13.12.00; accepted 15.01.01

Edited by L Fesus

\begin{abstract}
Although multiple functions for the small heat shock protein HSP25 have been proposed, its specific role during developmental and differentiation processes is not known. Cartilage is one of the tissues in which HSP25 is specifically and highly expressed during development. $\mathrm{C} 1 \mathrm{cells}$, able to form aggregates in vitro, can be induced to differentiate into chondrocytes. In this study, we generated two stable transfected clones overexpressing HSP25 at two different levels. Cell morphology and growth rate were modified in both clones, although the actin content and distribution did not seem to be altered. Overexpressing clones had more difficulties in coalescing, leading to smaller aggregates and they did not differentiate into chondrocytes. Subsequently, these aggregates tended to dissociate into loose masses of dying cells. The strength of all these effects was directly correlated to the level of HSP25 overexpression. These data suggest that overexpressing HSP25 decreases cellular adhesion and interferes with chondrocyte differentiation. Cell Death and Differentiation (2001) 8, 603-613.
\end{abstract}

Keywords: small heat shock proteins; HSP25; cell adhesion; chondrocyte differentiation; cell death

Abbreviations: BSA, bovine serum albumin; DMEM, Dulbecco's modified Eagle's medium; GSH, reduced glutathione; PBS, phosphate buffer saline; SDS, sodium dodecyl sulfate; SSC, standard saline concentration

\section{Introduction}

HSP25 (called HSP27 in human cells) belongs to the small heat shock protein family. Members of this protein family share similar structural features : a small molecular size (20-
$30 \mathrm{kDa}$ ) and a highly conserved carboxy terminal region, called the $\alpha$-crystallin domain. ${ }^{1}$ HSP2 5 was the first small heat shock protein to be described and its synthesis is highly induced in response to heat shock as well as chemical and oxidative stresses. $\alpha \mathrm{A}$ - and $\alpha \mathrm{B}$-crystallin were initially described as eye lens structural proteins. Yet, $\alpha \mathrm{B}$-crystallin shares similar function and sequence with HSP25. It can be induced by heat, chemical and oxidative stresses. The roles of these proteins as chaperones are well documented. ${ }^{2}$ The HSP25 distribution pattern has been studied in both adult mice and during the embryonic development. ${ }^{3-7}$ It appears to be highly expressed in specific organs or tissues such as the heart, ${ }^{8}$ skeletal striated muscles, epidermis, cartilage, bone ${ }^{9}$ and specific areas of the central nervous system. ${ }^{10,11}$ But nothing is known about how the possible role of this protein may explain such a specific distribution.

Several roles have been proposed for HSP25 from in vitro studies. It is well documented that it can interfere with actin polymerization and stabilization of microfilaments ${ }^{12-14}$ and HSP25 phosphorylation (through the p38 kinase pathway) is necessary for stress fibers and actin filament dynamics regulation. ${ }^{15-20}$ It could also interact with intermediate filaments and microtubules, ${ }^{21-23}$ although no direct proof has been given. This is in good agreement with the morphological modifications and changes in the cell proliferation rates observed in several cellular systems where this protein is over or underexpressed. ${ }^{24-26}$ Another role has been proposed by the laboratory of Dr. A-P Arrigo : it could act as a switch between differentiation and apoptosis as demonstrated during cell line differentiation in vitro. ${ }^{27,28}$ This role has been correlated with reduced glutathione regeneration in response to stress. ${ }^{29,30}$ But the cellular mechanism is not clearly identified yet for the action of HSP25 in the differential control of differentiation and apoptosis.

We were interested in understanding mechanism of HSP25 action at the cellular level and during the physiological process of differentiation. Our work has focused on cartilage differentiation. Cartilage is one of the tissues where HSP25 is most highly expressed apart from in the heart and skeletal muscles, both in the adult mouse and throughout embryonic development. ${ }^{10}$ HSP25 quantity increases during chondrocyte maturation, but it is more weakly expressed in the bone.

In order to determine the role of HSP25 in this differentiation process, we aimed at modifying its expression through overexpression and evaluated the effects of this overexpression on chondrocyte differentiation. Chondrocyte maturation is usually studied using mesenchymal dissected explants, kept in culture. The disadvantage of such a system is that it consists in a mixture of different cell types. We used another system : the $\mathrm{C} 1$ cell line. This 
teratocarcinoma-derived cell line ${ }^{31,32}$ can, in vitro, be specifically differentiated into chondrocytes, osteocytes or adipocytes according to the inducer used. ${ }^{33}$

We have stably transfected $\mathrm{C} 1$ undifferentiated cells with an expression vector containing the complete HSP25 cDNA, selected two HSP25 overexpressing clones and studied the cartilage differentiation capacities of these clones. Our results show that HSP25 overexpression disturbs cell adhesion resulting in the alteration of chondrocyte differentiation in the $\mathrm{C} 1$ cells.

\section{Results}

\section{Screening of HSP25 overexpressing clones}

In order to obtain HSP25 overexpressing clones, C1 cells were transfected with an expression plasmid carrying the complete HSP25 cDNA sequence, in sense orientation, under the control of the SV40 promoter and polyadenylation signal (see Material and Methods). A second plasmid was cotransfected for hygromycin resistance selection. After 3 weeks, hygromycin resistant clones could be detected. Seventeen of them, named sense clones, S, were picked and further sub-cloned. Figure $1 \mathrm{~A}$ displays the results of a Western blot conducted on protein extracts from nine independent clones. S1-1, S4-2, S5-2, S5-3, S8-3 correspond to clones transfected with the HSP25 cDNA containing plasmid. C1 are untransfected control cells. P1-1, P4-3, P6-8, P8-2 correspond to $C 1$ cells transfected with both the hygromycin resistance plasmid and the empty expression

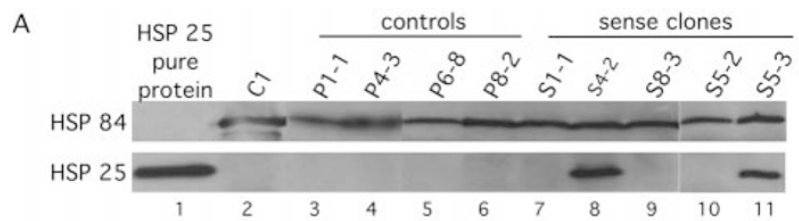

B

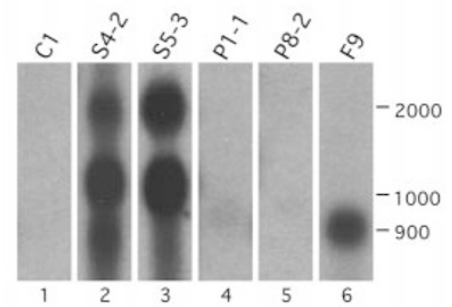

Figure 1 HSP25 levels in overexpressing clones. (A) HSP25 protein is overexpressed in two stably transfected clones. Ten $\mu \mathrm{g}$ protein from each cell extract was used in HSP25 and HSP84 immunoblot analyses of control untransfected $\mathrm{C} 1$ cells (lane 2), C1 cells transfected with the pSVK3 empty plasmid (P1-1, P4-3, P6-8, P8-2: lanes 3-6) or with the HSP25 containing plasmid (sense clones: lanes 7-11). Lane 1 contains $100 \mathrm{ng}$ purified HSP25 protein (StressGen, Canada). (B) HSP25 protein levels are correlated with transcription of the transgenes. Twenty $\mu \mathrm{g}$ of total RNA was loaded in each lane and resolved by $1 \%$ agarose gel electrophoresis. A cDNA probe, mapping to the $5^{\prime}$ part of the HSP25 transcript, was used for Northern blot analysis. The appropriately sized band was detected in clones overexpressing HSP25 (S4-2 and S5-3) but not in nontransfected cells (C1) or C1 containing vector alone (P1-1, P8-2). For comparison, lane 6 contains RNA from F9 cells, which constitutes a positive control for HSP25 endogenous transcription. Approximate size of the bands is indicated in nucleotides vector pSVK3 with no HSP25 insert. No HSP25 protein can be detected in proliferating untransfected $\mathrm{C} 1$ cells (lane 2 ), or in cells transfected with the empty vector ( $P$ clones: lanes 3, 4, 5, 6). This indicates that HSP25 is barely, if at all, expressed in proliferating $\mathrm{C} 1$ cells. Two highly overexpressing clones are detected: S4-2 (lane 8) and S5-3 (lane 11). The HSP25 content of S4-2 is slightly higher than that of S5-3. Further quantitation has been conducted on Western blots, comparing HSP25 content in S4-2 and S5-3 protein extracts, to known amounts of pure HSP25 protein (data not shown). S4-2 contains about $250 \mathrm{ng} \mathrm{HSP25/mg} \mathrm{total} \mathrm{protein} \mathrm{whereas} \mathrm{S5-3}$ content is about $150 \mathrm{ng} / \mathrm{mg}$ total protein. The expression level in clone S4-2 is thus 1.6 times higher than in S5-3. No protein was detected in the $\mathrm{C} 1$ extract, meaning those cells contained less than $10 \mathrm{ng} / \mathrm{mg}$ total protein. HSP84 protein content, used as an internal control, was not modified in HSP25 overexpressing clones, indicating no global HSP alteration.

Northern-blot analysis of RNA extracted from proliferating S4-2 and S5-3 cells has confirmed these results (Figure 1B). No HSP25 RNA could be detected in C1 cells (lane 1), or in $\mathrm{P}$ clones extracts (lanes 4 and 5); therefore transfection in itself does not affect HSP25 expression. In contrast, two major bands are revealed in S4-2 and S5-3 cells (lanes 2 and 3 ). The upper band corresponds to the expected size of the transgene RNA (about $1900 \mathrm{nt}$ ) using the SV40 polyA signal. The lower band corresponds to the size of a transcript which uses the polyA signal present at the $3^{\prime}$ end of the HSP25 cDNA insert. It leads to a transgene transcript of about $1000 \mathrm{nt}$. Both bands display higher molecular size than the endogenous HSP25 mRNA, which is about $900 \mathrm{nt}$ long $^{34,35}$ as seen in the F9 cell extract (lane 6) in which HSP25 is constitutively expressed. A third, smaller (less than $900 \mathrm{nt}$ ) and fainter, signal is detected in clone S4-2. It might correspond to the use of an internal transcriptional initiation signal and lead to a partial transcript.

Thus, HSP25 protein overexpression observed in S4-2 and S5-3 clones (Figure 1A, lanes 8 and 11) is correlated with high amounts of HSP25 transgene RNAs.

\section{HSP expression in proliferating cells of control and HSP25 overexpressing clones}

HSP25 distribution in C1 control and overexpressing cells was examined by immunofluorescent staining of fixed cells (Figure 2). In $\mathrm{C} 1$ cells, despite the absence of a signal in Western and Northern-blot analyses, a faint staining can be detected in the cell cytoplasm (Figure 2a). In S4-2 (Figure 2e) and S5-3 (Figure 2i) cells, a strong signal is detected. It is uniformly distributed in the cytoplasm with no nuclear coloration. No protein aggregates could be detected even when observed at higher magnification. Thus, overexpression of HSP25 in S4-2 and S5-3 clones does not appear to alter the global cellular distribution of this protein and does not lead, in our case, to macroscopic HSP25 aggregates.

HSP84, used as control, as well as other small HSPs $(\alpha \mathrm{B}$-crystallin, MKBP) expression patterns are not modified by HSP25 overexpression. HSP84 (Figure 2b,f,j) displays a specific perinuclear localization in highly colored bubble shaped compartments. $\alpha \mathrm{B}$-crystallin staining is similar in all 

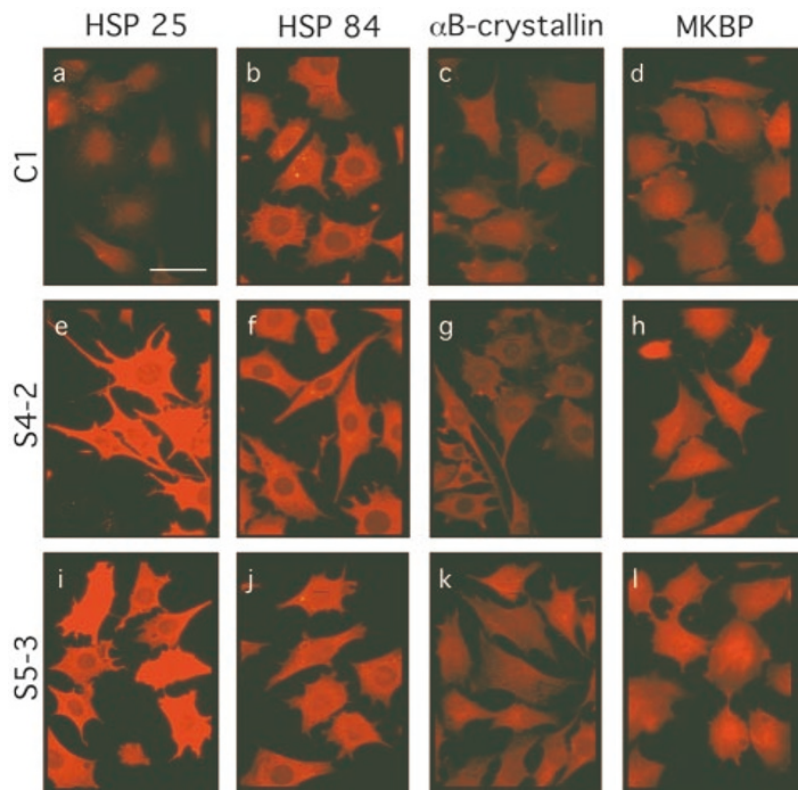

Figure 2 HSP25 overexpression does not modify the expression of other HSPs in proliferating cells. Proliferating cells of $\mathrm{C} 1(\mathbf{a}, \mathbf{b}, \mathbf{c}, \mathbf{d})$ and HSP25 overexpressing clones S4-2 (e,f, $, \mathbf{g}, \mathbf{h})$ and S5-3 $(\mathbf{i}, \mathbf{j}, \mathbf{k}, \mathbf{l})$ were fixed and immunolabeled with anti HSP25, anti HSP84, anti $\alpha B$-crystallin, anti MKBP, followed by appropriate cy3-linked secondary antibodies. Though the level of HSP25 in clones S4-2 and S5-3 is increased overall (e,i), it remains predominantly cytoplasmic. The expression level and the distribution of related small HSPs, $\alpha$ B-crystallin $(\mathbf{c}, \mathbf{g}, \mathbf{k})$ and MKBP $(\mathbf{d}, \mathbf{h}, \mathbf{l})$, and another HSP, HSP84 (b,f,j), are not altered by HSP25 overexpression. Bar: $40 \mu \mathrm{m}$

three clones and close to what can be seen in $\mathrm{C} 1$ cells for HSP25 (Figure 2c,g,k). MKBP is a third member of the smHSPs family, primarly described in the heart tissue. ${ }^{36}$ Its expression is homogenous (Figure $2 \mathrm{~d}, \mathrm{~h}, \mathrm{l})$ ). These results underline the specificity of HSP25 overexpression.

\section{Cell proliferation in control and HSP25 overexpressing clones}

HSP25 overexpression seems to be correlated, in some transfected cellular systems, with reduced (A-P Arrigo, personal communication) or increased ${ }^{37}$ proliferation rate. In order to estimate the length of the cell cycle, we analyzed growth kinetics. The three clones of interest, C1, S4-2 and S53 , were initially plated at similar densities, then harvested and counted in triplicate, for the following 9 days. Growth curves are illustrated on Figure 3. Statistic comparison (Anova test) of the exponential phase of the growth curves shows that S4-2 and S5-3 doubling times are statistically different from that of C1 $(P=0.001)$ and are about 22 and $19 \mathrm{~h}$, respectively, whereas the doubling time of $\mathrm{C} 1$ is $14 \mathrm{~h}$. Thus, both HSP25 overexpressing clones display reduced (up to 57\%) proliferation rates when compared to untransfected $\mathrm{C} 1$ cells. The amplitude of the decrease is correlated with the level of HSP25 overexpression (S4-2: 57\%; $250 \mathrm{ng} / \mathrm{mg}$ and S5-3: $35 \% ; 150 \mathrm{ng} / \mathrm{mg}$ ).

Morphological alterations can also be detected in HSP25 overexpressing clones. C1 cells are polygonal cells and are generally quite large and flat (about $40 \mu \mathrm{m}$ diameter)
A

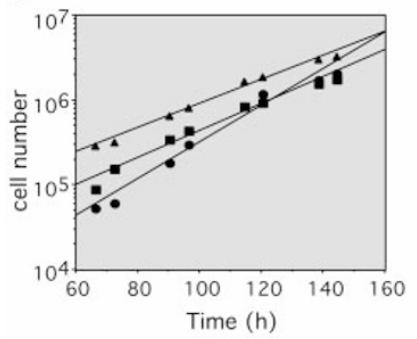

B

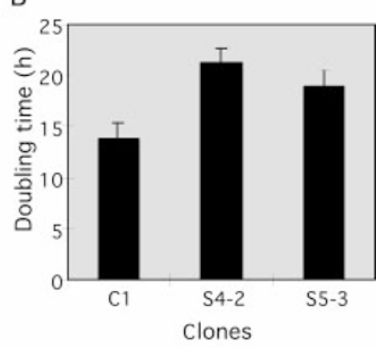

Figure 3 Proliferation rate is reduced in HSP25 overexpressing clones. (A) Semi-logarithmic representations of cell number versus time of culture (in hours). Initial seeding was at $10^{5}$ cells $/ 6 \mathrm{~cm}$ tissue culture dish. Each point corresponds to the mean of a triplicate. $\mathbf{S} 4-2 \square$ S5-3 $\bigcirc$ cells. (B) The slope of the curves obtained in $\mathbf{A}$ was used to calculate the mean and standard deviation of the cells doubling times. The doubling time was significantly increased in clones S4-2 and S5-3 compared to parental C1 cells
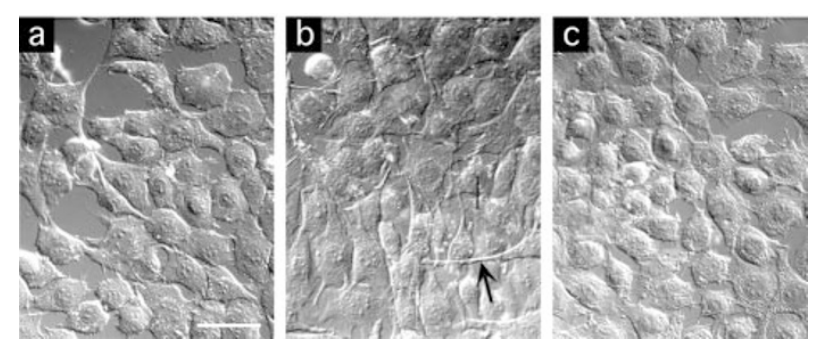

Figure 4 Morphology proliferating C1 cells and HSP25 overexpressing S4-2 and S5-3 clones. Microscopic images taken using Nomarski interference contrast of C1 (a), S4-2 (b) and S5-3 (c) half confluent cells demonstrate the altered phenotype of S4-2 and S5-3 cells. The arrow indicates one of the thin prolongations typical of S4-2 cells. White bar: $50 \mu \mathrm{m}$

(Figure 4a). S4-2 cells were much longer and thinner with a fibroblast-like morphology (see Figures $4 b$ and $2 e-h$ ). S5-3 displayed an intermediate phenotype.

\section{Actin filaments in control and HSP25 overexpressing cells}

The previous observations and literature data led us to compare HSP25 localization with that of some cytoskeleton components. Cellular actin filaments can easily be visualized using fluorescein-linked phalloidin. No difference could be detected between the different clones in their actin network, either in the distribution of the filaments, or in their lengths: overexpression of HSP25 does not seem to globally disturb the actin filament network in these cells (Figure $5 b, e, h$ ). When the actin and HSP25 signals were superimposed (Figure $5 \mathrm{c}$, $\mathrm{f}, \mathrm{i})$, we observed an overlapping signal (yellow) in S4-2 and S5-3 clones. The predominant green signal in $\mathrm{C} 1$ cells (Figure 5c) reflects their low HSP25 content.

\section{Chondrogenic differentiation of control and HSP25 overexpressing clones}

C1 cells have been described as a practical system to study chondrocyte differentiation. Upon dexamethasone addition, cells differentiate into proliferating, then mature and 

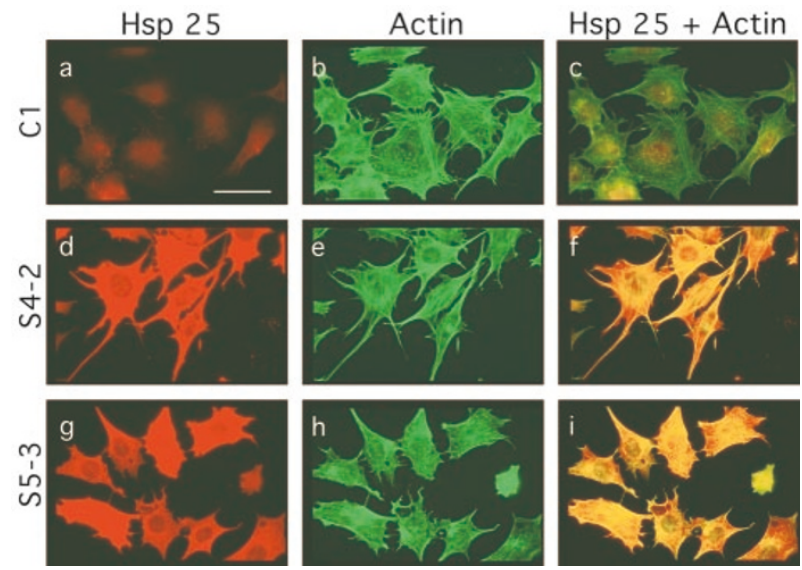

Figure 5 The actin filamentous network and HSP25 distribution overlap in HSP25 overexpressing S4-2 and S5-3 clones. Proliferating cells of C1, S4-2 and S5-3 clones were fixed and labeled with FITC-linked phalloidin and anti HSP25 followed by a cy3-linked secondary antibody. Double exposure of cy3 and FITC fluorescence $(\mathbf{c}, \mathbf{f}, \mathbf{i})$ demonstrates the colocalization of HSP25 and actin. Bar: $40 \mu \mathrm{m}$

subsequently hypertrophic chondrocytes, expressing in vitro several cartilage specific markers such as collagen II and collagen $X^{31-33}$ This differentiation process requires an initial aggregation step ( 9 days named d-9 to d0) when cells proliferate and form spherical aggregates. These aggregates continue growing in size during the first 20 days of differentiation but begin to differentiate after inducer treatment (dexamethasone is added at $\mathrm{d} 0$ ). ${ }^{33}$ All analysis were performed on aggregates harvested at four different stages: day 0 ( $\mathrm{d} 0=$ =induction), 12 (d12), 26 (d26) and 48 (d48).

\section{Formation of the aggregates}

During the initial aggregation step (from d9 to d0), we noticed that HSP25 overexpressing cells had difficulties in forming aggregates. Figure $6 \mathrm{~A}$ shows the detailed size distribution of the aggregates, estimated at d0 (see Materials and Methods): the radius of $\mathrm{C} 1$ aggregates covers a large range of sizes, reaching values of over $125 \mu \mathrm{m}$ (Figure 6A, a); the size distribution of S4-2 and S5-3 also covers a wide range, but never exceeds $90 \mu \mathrm{m}$ for S5-3 (Figure 6A, c) and hardly reaches $80 \mu \mathrm{m}$ for $\mathrm{S} 4-2$ (Figure $6 \mathrm{~A}, \mathrm{~b}$ ). The mean radius of the aggregates formed from S4-2 and S5-3 cells was smaller than the mean radius of those formed by $\mathrm{C} 1$ cells: while $\mathrm{C} 1$ aggregates had an average radius of $58 \mu \mathrm{m}$, the average radius was $20 \%$ and $38 \%$ lower for S5-3 (46 $\mu \mathrm{m})$ and S4-2 (36 $\mu \mathrm{m})$, respectively (Figure 6B). Statistical analysis (t-test) revealed these differences to be highly significant (Figure $6 \mathrm{C}$ ). It should be noticed that the difference in cell growth rate mentioned above cannot account for the differences in the size of the aggregates. Indeed, when the starting densities are increased, the number of aggregates increases, but their average size remains the same (data not shown).

Between d0 and d12, S4-2 aggregates completely dissociated. Only clone S5-3 could be followed in differentiation until $\mathrm{d} 48$. Thus, most of the following data only concern $\mathrm{C} 1$ and S5-3 clones.
A

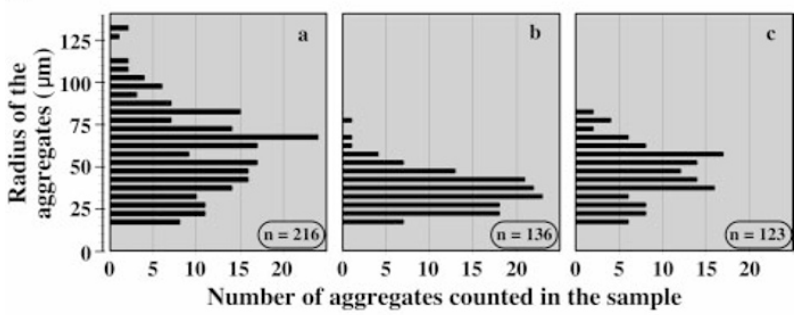

B

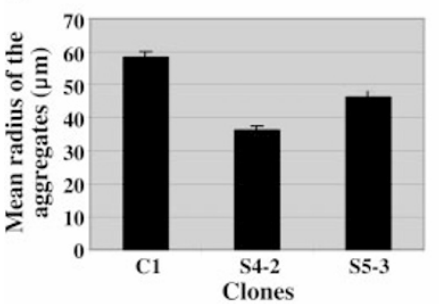

C

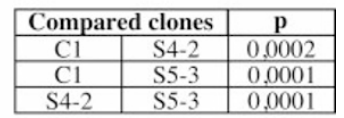

Figure 6 Comparison of the size of cellular aggregates at the end of the compaction phase. At day 0 , aggregates were collected and their radii calculated as described in Materials and Methods. (A) The size distributions, in terms of radius, established for C1 (a), S4-2 (b) and S5-3 (c) aggregates indicate a reduced proportion of large aggregates in the clones expressing HSP25. (B) Mean radius and standard error calculated, for each clone, from the data above. (C) The results of the statistical test ( $t$-test) show a significant size difference between each of the three clones

\section{Differentiation markers}

The differentiation of cartilage was followed by analyzing the expression of collagens I and II, two main markers of this differentiation (Figure 7). Collagen I is a specific marker of bone, absent from the mature and hypertrophic chondrocyte stages, but known to be expressed in chondroprogenitor cells. ${ }^{38}$ As for collagen II, it is a specific marker of mature and hypertrophic chondrocytes. Our results of Northern-blot analysis of $\mathrm{C} 1$ aggregates at d0, 12, 26 and 48 (Figure 7A) confirm previous observations. ${ }^{33}$ Collagen I expression, already significant at d0 (lane 1) is maximum at d12 (lane 2 ), then decreases at d26 and d48 (lanes 3 and 4). Collagen II expression, in contrast, is weak at d0 (lane 1), increases until d26 and then remains high. In S5-3 aggregates, collagen I and II expression appeared similar to that observed in C1 clone at d0 (lane 5). But their expression is drastically reduced as early as d12, both for collagen I and collagen II (lane 6). The latter does not increase as expected in normal differentiation and is totally absent at d26 and d48 (lanes 7 and 8). This clearly demonstrates that expression of collagen markers was altered in HSP25 overexpressing cells. The corresponding protein expression was examined by immunocytochemistry of sections of the aggregates. This is represented in Figure 7B for the cartilage specific collagen, collagen II. These observations support the results of the Northern blot. Collagen II expression increased in C1 aggregates until d26 and then decreased (Figure 7B, a-d). In S5-3 aggregates, it was at a low level at d0, it remained faint at d26 and then completely disappeared (Figure 7B, e-h). Alcian blue staining was also performed on aggregate sections. This dye colors sulfated glycosaminoglycans of the extracellular matrix and is thus specific to cartilage matrix. 
A

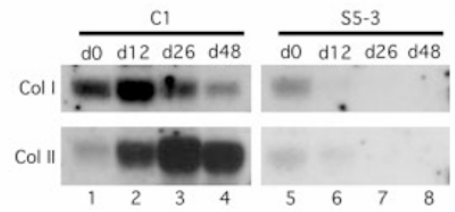

B

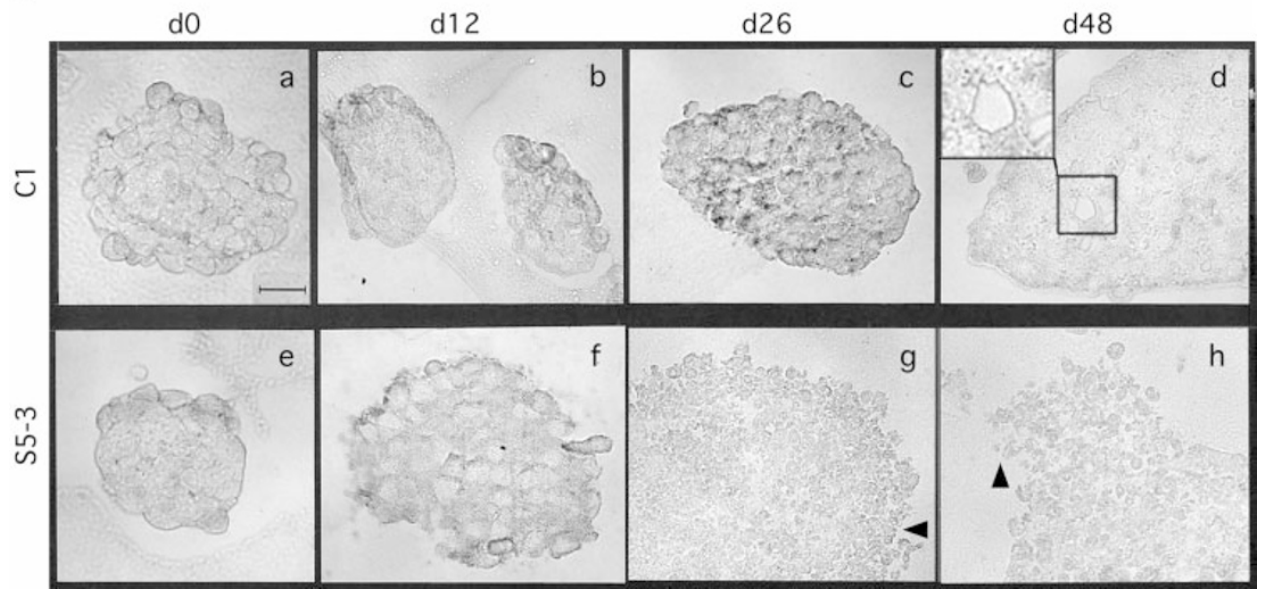

Figure 7 Collagen I and II expression in C1 aggregates is characteristic of chondrocyte differentiation whereas they are altered in HSP25 overexpressing S5-3 clone. (A) Specific cDNA probes were used for Col I or Col II detection in Northern-blot experiments. During the differentiation of C1, tested at the time points indicated, mRNA for collagen I appears transiently with a peak at d12, and collagen II appears progressively until d26 and decreases afterwards (lanes 1-4). In contrast, little signal was detected in differentiating S5-3 (lanes 5-8). (B) C1 (a-d) and S5-3 (e-h) aggregates harvested at indicated timepoints were fixed, embedded in paraffin and sections labeled with anti-collagen II antibody. During the differentiation, the appearance of collagen II protein in the C1 aggregates was also progressive until d26. It was reduced at d48. Little collagen protein was detected in S5-3. The inset in (d) shows the detail of a lacuna ( $2 \times$ enlargement with enhanced contrast). Arrowheads indicate the dissociation of cells on the edge of S5-3 aggregates at d26 and d48

A blue coloration appears as early as d26, a stage which corresponds to chondrocyte maturation and to the expression of collagen II. Staining continues at later stages when the extracellular matrix is more abundant, surrounding a few living cells in lacunae. With S5-3 aggregates, no blue coloration could be seen in the first stages (d0, d12) and further dissociation of the aggregates did not allow confident staining of aggregates (data not shown).

Collagen I and II expression and Alcian blue staining in C1 aggregates all confirm previous in vitro observations in the $\mathrm{C} 1$ system and in vivo kinetics of cartilage differentiation. Therefore, the alteration observed with S5-3 clone for those two aspects of the differentiation tend to indicate that cartilage differentiation was altered by HSP25 overexpression.

\section{Morphology of the aggregates}

Characteristic morphological changes can be noticed during the cartilage differentiation process of $\mathrm{C} 1$ cells. Aggregates first appear as homogenous, compact, cell gatherings. Cell division ceases around day 26 (d26) when chondrocytes become mature. Chondrocytes then increase in size becoming hypertrophic chondrocytes and secrete abundant extracellular matrix. Lacunae begin to form, surrounded by abundant matrix and including rare living cells. This characteristic aspect of $\mathrm{C} 1$ aggregates at $\mathrm{d} 48$ can be seen in Figure 7B, d. Morphological aspects of the aggregates therefore constitute good indicators of the differentiation process. It should also be mentioned that even the $\mathrm{C} 1$ aggregates which were of a size comparable to the mean size of S5-3 aggregates had this morphology.

As noticed above, from immunological observations (Figure 7B), the morphology of S5-3 aggregates seems to be altered : they look like $\mathrm{C} 1$ aggregates at the early stages (d0, d12), with similar shapes and cell boundaries (Figure 7B, e-f). By d26, HSP25 overexpression leads to less cohesive aggregates which tend to disassemble and display more diffuse cellular boundaries; also, nuclei were not as clearly distinguishable (Figure 7B, g-h). Furthermore, the classical morphology of hypertrophic cartilage as detected in $\mathrm{C} 1$ cells was never observed in HSP25 overexpressing clones. No lacunae and no embedding of large cells in extracellular matrix could be seen (compare Figure 7B, d,h).

The analysis of the shape of whole aggregates (Figure 8) led to similar conclusions : S5-3 aggregates are shaped like $\mathrm{C} 1$ aggregates until d12 (Figure 8a,b,e,f), even though they remain smaller (see Figure 6); then they become loose masses of dissociating cells (Figure $8 \mathrm{c}, \mathrm{d}, \mathrm{g}, \mathrm{h}$ ). This modified morphology was observed in all S5-3 aggregates but never, at any stage, in $\mathrm{C} 1$ aggregates.

We mentioned above that S4-2 aggregates were completely dissociated as early as d12. Thus, the different 
observations for S4-2 and S5-3 may be accounted for by a change in adhesive properties that would occur sooner in S4-2 which expresses a higher level of HSP25.

In order to clarify whether these morphological changes were correlated with cell death, we observed nuclei after Hoechst coloration of $\mathrm{C} 1$ and S5-3 aggregates throughout the differentiation process (Figure 9). Nuclei appeared with clear limits in $\mathrm{C} 1$ aggregates at all stages of differentiation (Figure $9 a-d$ ). The aggregates initially appeared compact (d0, d12) whereas nuclei progressively appeared more distant from one another reflecting the increase in cell spacing due to extracellular matrix deposition (d26, d48). The nuclei do not seem to be modified in the early stages of differentiation ( $\mathrm{d} 0$ : Figure $9 \mathrm{e}$ ) in S5-3 aggregates, even though the aggregates did not contain as many cells as C1 aggregates. But nuclear integrity was severely affected by stage d26 when nuclei could hardly be seen. The Hoechst reagent colored small spots distributed in the whole aggregate (Figure 9g). This phenomenon was further accentuated at d48 when ever fewer intact nuclei were detected (Figure 9h). Nuclear integrity was thus altered as early as d12 in S5-3 cells and this continued until d48. This demonstrates that the cells remaining in S5-3 aggregates at d26 are probably

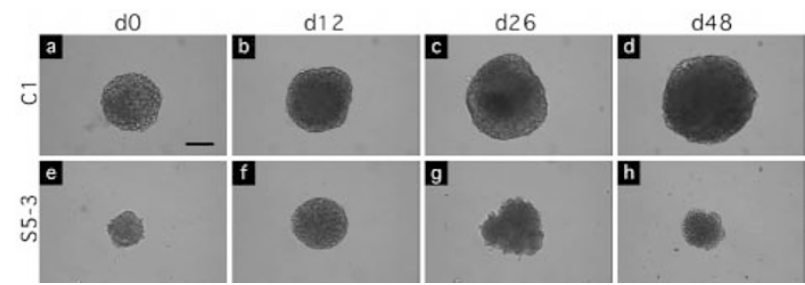

Figure 8 HSP25 overexpressing clones formed smaller and looser aggregates than $\mathrm{C} 1$. Phase contrast micrographs of aggregates of $\mathrm{C} 1(\mathbf{a}-\mathbf{d})$ and S5-3 $(\mathbf{e}-\mathbf{h})$ clones, fixed, at d0, d12, d26 and d48 of differentiation indicate the dramatically altered size and morphology of S5-3 aggregates. Bar: $100 \mu \mathrm{m}$ dying, due to a process which could begin even earlier, between $\mathrm{d} 12$ and $\mathrm{d} 26$ of differentiation and which is not observed in $\mathrm{C} 1$ parental cells.

\section{Reduced glutathione level in control and HSP25 overexpressing clones}

Given that HSP25 has been proposed to protect against apoptosis via the metabolism of glutathione, ${ }^{29,30}$ we were interested in following the level of reduced glutathione (GSH) in both clones, throughout the differentiation process (Figure 10). At d0, the level of $\mathrm{GSH}$ is 2.5 higher in S5-3 than in $\mathrm{C} 1$ aggregates. A significant difference was also detected in non-differentiating dividing cells, between the three clones C1, S4-2 and S5-3 : GSH concentration was approximately 7.6, 22.5 and $16.6 \mathrm{nmoles} / \mathrm{mg}$ total protein for C1, S4-2 and S5-3 respectively (data not shown). These data suggest that

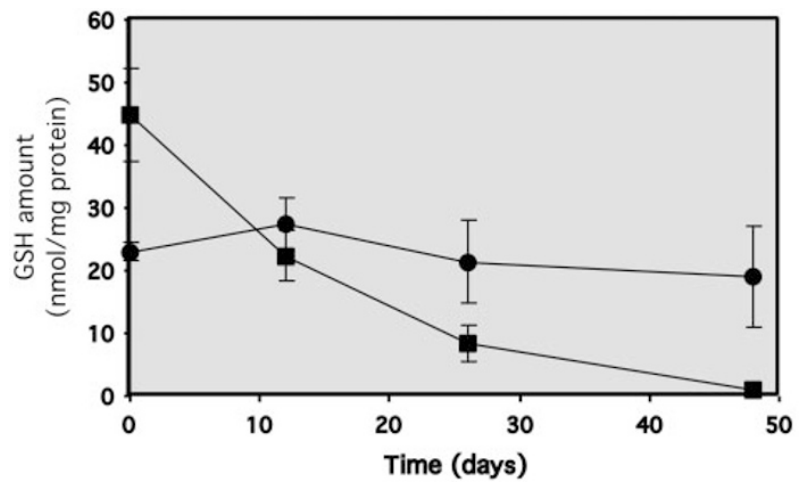

Figure 10 The level of reduced glutathione is altered during chondrocyte differentiation of the $\mathrm{C} 1$ and $\mathrm{S} 5-3$ clones. Reduced glutathione (GSH) was measured in triplicate for each clone and at each time point over 48 days of differentiation and normalized to total protein content. Although S5-3 cells initially contained significantly higher levels of GSH, this level dramatically decreased during differentiation, while the content of GSH in $\mathrm{C} 1$ cells remained constant. $\square$ S5-3 $\mathrm{C} 1$ aggregates
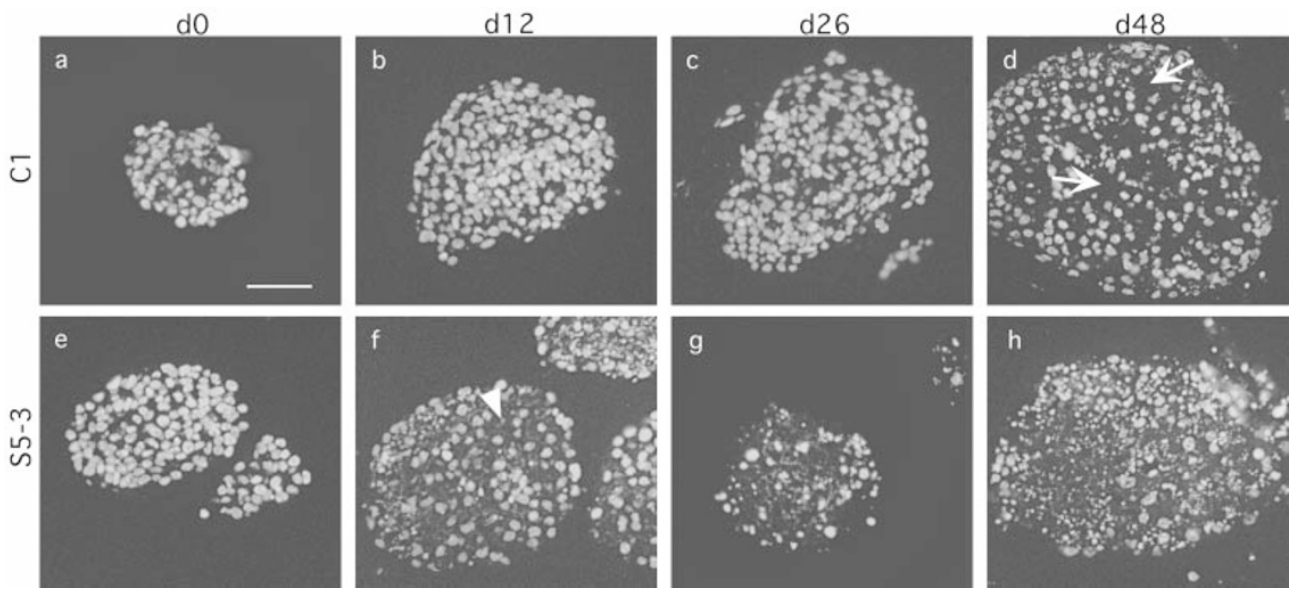

Figure 9 The nuclei degenerate during chondrocyte differentiation of the HSP25 overexpressing S5-3 clone. C1 (a-d) and S5-3 (e-h) aggregates were fixed and sections were labeled with Hoechst 33342 at d0, d12, d26 and d48 of chondrocyte differentiation. Arrows point to black areas corresponding to lacunae and extracellular matrix present in $\mathrm{C} 1$ aggregates at $\mathbf{d 4 8}(\mathrm{d})$. The arrowhead shows bright spots which presumably indicate the degenerating nuclei of dying cells (see text). These spots are visible in S5-3 aggregates from as early as d12 (f) and increase in quantity at d26 (g) and d48 (h). Bar: $100 \mu \mathrm{m}$ 
the higher level of $\mathrm{GSH}$ is related to the overexpression of HSP25. After d0, the level of GSH remains constant in C1 cells, at around 20 nmoles $/ \mathrm{mg}$ protein. In S5-3 aggregates, this level, initially higher than in $\mathrm{C} 1$, rapidly falls from $45 \mathrm{nmoles} / \mathrm{mg}$ protein (d0) to $20 \mathrm{nmoles} / \mathrm{mg}$ protein (d12) and then to less than $10 \mathrm{nmoles} / \mathrm{mg}$ protein at $\mathrm{d} 26$, being undetectable after $\mathrm{d} 48$. These variations seem to be correlated to the dissociation of the aggregates and the changes in the appearance of the nuclei described above.

\section{Discussion}

Though HSPs have long been studied with regard to their role in cell protection in response to various stresses, recent studies give insights into their possible specific roles in development. HSP25 is the paradigm of small heat shock proteins in mammalian cells. It has been studied in a few cellular systems and to a lesser extent in the whole animal. Its study in postnatal or adult mouse or rat, as well as in the developing embryo ${ }^{3,4,9,10,39}$ underlines its specific and very high expression in several organs and structures.

A few cellular systems only have been used to study HSP25 role in cell differentiation. ${ }^{27,28,40-43}$ Recently, P19 cells have been analyzed more extensively. ${ }^{8}$ HSP25 content increases drastically during cardiomyocyte differentiation and fewer beating cells can be seen when HSP25 expression was inhibited by antisense transfection. But HSP25 does not seem to be necessary for neuronal differentiation of P19 cells.

We were interested in investigating HSP25 expression and its role in another differentiation process : chondrogenesis. HSP25 content has been shown to increase throughout chondrogenesis of the mouse embryonic limb. ${ }^{9}$ The amount of this protein is far lower than in striated muscles (cardiac and skeletal), but it increases in parallel with chondrocyte growth, maturation and with hypertrophic chondrocyte formation when extracellular matrix calcifies. C1 cells are a good cellular system to study mouse chondrogenesis in vitro. ${ }^{33}$

\section{Overexpression of HSP25}

Stable overexpression of HSP25 was used in the C1 cellular system to understand the small HSP activity in this differentiation process. Overexpression of genes has proven to be very useful in cell systems where redundant genes exist. ${ }^{44}$ In contrast to antisense-type experiments, this method can lead to enhanced phenotypes which are not hidden by the contribution from redundant genes. In the case of HSP25, $\alpha \mathrm{B}$-crystallin might play a similar role, as well as, though their similarities are lower, MKBP, ${ }^{36}$ p20, ${ }^{45}$ $\mathrm{HspB}^{46}$ or the recently discovered cvHsp. ${ }^{47}$ Thus, we transfected $\mathrm{C} 1$ cells with the complete HSP25 cDNA and selected stable transformants. Two overexpressing clones were obtained, showing different amounts of HSP25. These cells did not show any difference in the content of the other HSPs investigated (HSP84, $\alpha \mathrm{B}$-crystallin and MKBP).

\section{HSP25 and the cytoskeleton}

Overexpression of HSP25 is accompanied by morphological changes. C1 cells are polygonal cells, about $40 \mu \mathrm{m}$ in diameter. S4-2 were dramatically modified in their shape, being long and thin, with thin extensions, in a fibroblast-like shape. S5-3 cells are also morphologically distinguishable from $\mathrm{C} 1$ cells, although those alterations are less evident than for S4-2.

Overexpression of HSP25 was also associated with a reduction in cell growth rate. The doubling time was $157 \%$ that of $\mathrm{C} 1$ in S4-2 cells and $135 \%$ in S5-3. Thus, overexpression of HSP25 tends to reduce cell proliferation in a way which is directly correlated with the small heat shock protein amount. Cell growth rate alteration due to HSP25 underexpression has been described: the cell division rate seems to be reduced in cells where HSP25 content is lowered (Arrigo, personal communication, ${ }^{24}$ ) but it has not been quantified. In cellular systems which overexpress HSP25, the cell growth rate has not been extensively investigated. ${ }^{12,48-50}$ Reduced expression as well as overexpression of HSP25 could lead to growth rate reduction, which emphasizes the importance of defined quantities of HSP25 in the cells to allow proper division. How a modification in HSP25 cellular amount could modify the cell growth rate remains unanswered.

HSP25 has been described in vitro as interfering with the actin filaments, preventing polymerization of globular actin into filaments, through reduction of the capping activity. ${ }^{15}$ The modifications of cell morphology and growth rate in clones which overexpress HSP25 and the correlation of these effects with the level of overexpression suggest that HSP25 could interfere with the cytoskeleton. However, no modification was detected in the actin amount and its distribution in the cells. This does not exclude local modification in the cytoplasm of the cells, but it was not detected by immunofluorescence cytology.

The role of HSP25 could be dependent on its phosphorylation state. ${ }^{14,51}$ The polymerization state of this protein also contributes to the regulation of its activity. ${ }^{52}$ In response to stress, HSP25 aggregates of higher molecular weight (up to $700 \mathrm{kDa}$ ) form, which are active, whereas smaller aggregates $(<200 \mathrm{kDa})$, inactive, are present in unstressed cells. Further investigations would have to be conducted on S4-2 and S5-3 clones to analyze the phosphorylation and polymerization states of HSP25, in exponentially growing as well as aggregating cells.

\section{HSP25 and chondrocyte differentiation}

As HSP25 expression has been shown to increase throughout differentiation of the mouse embryonic limb, ${ }^{9}$ we were interested in evaluating the role of HSP25 overexpression in chondrogenesis in vitro. The effect of HSP25 overexpression was followed only in $\mathrm{C} 1$ and S5-3 clones, since early dissociation of S4-2 aggregates did not allow us to collect enough aggregates of this clone to study chondrogenesis (for discussion of the role of HSP25 in disaggregation, see below). S5-3 differentiation seems to be altered. There is no formation of cartilage or lacunae such as can be seen in $\mathrm{C} 1$ 
aggregates. This was confirmed by collagen I and II studies (Figure 7). Whereas collagen II, a specific marker for cartilage formation, increases until d26 in $\mathrm{C} 1$ aggregates, it is present at d0 in S5-3 cells but totally absent from d12. This corresponds to a clear modification in collagen II expression. Similarly, collagen I, a marker of chondroprogenitors, is not expressed in S5-3 aggregates during differentiation except at d0, when it is transiently expressed during the differentiation of $\mathrm{C} 1$ cells, with a peak at d12. Thus, HSP25 overexpression leads to dramatic changes in the synthesis of the specific markers of chondrogenesis.

Cells within the S5-3 aggregates appear to have more diffuse borders and less defined nuclear envelopes than $\mathrm{C} 1$ cells (Figure 7B). Nuclei staining by Hoechst was completed to know whether cell death was occurring (Figure 9). C1 aggregates displayed intact nuclei at all stages of differentiation. In contrast, nuclear integrity was strongly altered in S5-3 cells as early as d12, even before the modifications which could be observed in the morphology of the aggregates. Only a few nuclei could be seen at d26 or d48. Clearly, most of the cells died in the aggregates as soon as d26 or even earlier. Whether this death is due to apoptosis or another mechanism remains to be studied.

It has been shown in a few cellular systems that reduced expression of HSP25 $24-26$ may induce a change in cell differentiation. The group of Arrigo has proposed that HSP25 could play a role as a switch between cell differentiation and apoptosis. ${ }^{27,28}$ In ES cells or olfactory neurons undergoing differentiation, a transient expression of HSP25 accompanies arrest of cell proliferation and entry into differentiation. When this increase is altered, more cells undergo apoptosis. This protection against apoptosis may be related to redox metabolism through glutathione regulation. $^{30,53}$ Thus, HSP25 could protect cells against apoptosis both under stressful conditions ${ }^{54-56}$ and during differentiation. Preville et al. ${ }^{29}$ have shown that HSP25 can increase reduced glutathione regeneration through control of the glucose-6-phosphate dehydrogenase activity.

Therefore, reduced glutathione content was followed throughout differentiation of both $\mathrm{C} 1$ and S5-3 cells. Whereas its level remains constant in $\mathrm{C} 1$ cells, it is initially higher in S5-3 cells and then dramatically decreases. The initially high level of reduced glutathione in S5-3 clone may be related to the overexpression of HSP25. In non-differentiating dividing cells, reduced glutathione content was also higher in S5-3 and S4-2 clones than in $\mathrm{C} 1$ : it was approximately 7.6, 22.5 and $16.6 \mathrm{nmoles} / \mathrm{mg}$ total protein for $\mathrm{C} 1, \mathrm{~S} 4-2$ and S5-3 respectively. Once again, these differences are correlated with the level of expression of HSP25. However, despite the high level of HSP25 protein in clone S5-3, a high level of reduced glutathione was not maintained throughout the whole process of chondrocyte differentiation treatment and cell death was not prevented.

\section{HSP25 and adhesion molecules}

The smaller size of the cellular aggregates formed from HSP25 overexpressing clones and their dissociation during chondrogenesis (between d0 and d12 for S4-2 and more slowly for S5-3) suggest that this protein could be involved in adhesion properties of these cells. Chondrogenesis is known to be highly dependent on the first step of condensation, both in vivo and in vitro. This differentiation process requires condensation of mesenchymal cells prior to proliferation, maturation and differentiation of chondrocytes. N-cadherin has been shown to be essential for this initial step in chicken chondrogenesis. ${ }^{57,58}$ It enables cell-cell interaction, in connection with fibronectin, laminin and $\alpha 5 \beta 1$ integrin receptor, ${ }^{59}$ thus enabling aggregate assembly. $\mathrm{N}$-cadherin is highly expressed in the early stages of cellular condensation and diminishes throughout differentiation. N-CAM has been described as being secondarily expressed. ${ }^{58}$ It contributes to stabilization of the cell-cell interactions initiated by $\mathrm{N}$-cadherin expression. The expression profile of this adhesion molecule is similar to that of $\mathrm{N}$-cadherin but slightly delayed. More recently, Chimal-Monroy et al. ${ }^{60}$ were also able to detect $\mathrm{N}$ cadherin and N-CAM proteins through Western-blot analyses of cell culture from forelimb buds of mouse.

The altered morphology observed in the aggregates which tend to dissociate during differentiation (see Figure 8), at a rate which correlates with HSP25 overexpression level, supports the hypothesis that HSP25 overexpression could interfere with adhesion molecules in a way which reduces cell condensation. Adhesion molecules such as $\mathrm{N}$ cadherin, N-CAM and integrins, which are involved in the early stages of chondrogenesis, are also known to interact with microfilaments and intermediate filaments of the cytoskeleton, either directly or through intracytoplasmic proteins. ${ }^{61}$ As HSP25 is known to interact with actin and intermediate filaments, this protein could play a role as a linking protein between integrin receptors and the cytoskeleton.

In summary, the overexpression of HSP25 in C1 cells leads to dramatic changes in the shape of the cellular aggregates, possibly by interfering directly or indirectly with cell adhesion molecules, and thereby prevents chondrogenic differentiation.

This phenomenon appears to be important since HSP25 expression has also been reported to be increased in several tumor cells which are resistant to chemotherapeutic agents; ${ }^{37,50}$ for a review, see. ${ }^{62}$ If overexpression of HSP25, as we show here, also reduces or modifies cellcell adhesion properties, this could be of major clinical consequences since the HSP25 overexpressing tumor cells, which appear to be resistant to cytotoxic drugs, could also more easily separate from the tissue and promote metastases.

\section{Materials and Methods}

\section{Transfection}

$\mathrm{C} 1$ cells were transfected by $\mathrm{CaPO}_{4}$ precipitation using the plasmid pKJ23 encoding hygromycin resistance alone or with a 10-fold excess of the expression vector PSVK3 (Pharmacia, Sweden) engineered to contain the murine HSP25 cDNA in sense orientation under the control of the SV40 promoter. ${ }^{27,63}$ Resistant cells were selected in $200 \mu \mathrm{g} / \mathrm{ml}$ 
hygromycin and single clones isolated and tested for the level of HSP25 protein by immunoblot. Among 17 independent clones analyzed, two showed a significant and reproducible increased level of HSP25 on immunoblots.

\section{Cell culture and differentiation}

$\mathrm{C} 1$ cells and transfectants were cultured in tissue-culture dishes (Falcon) at $37^{\circ} \mathrm{C}$ in $7.5 \% \mathrm{CO}_{2}$ water-satured atmos-phere in DMEM medium (Gibco) containing 10\% heat-inactivated fetal calf serum, $1 \mathrm{mM}$ pyruvate, $2 \mathrm{mM}$ glutamine, $50 \mu \mathrm{g} / \mathrm{ml}$ streptomycin and 50 units/ $\mathrm{ml}$ penicillin. To carry out the differentiation, $\mathrm{C} 1$ or transfectants were seeded at $3 \times 10^{5}$ cells per $10 \mathrm{ml}$ of culture medium in untreated plastic dishes to form cell aggregates. After 9 days (day 0), the aggregates were re-fed with DMEM (serum-free) supple-mented with $1 \mathrm{mM}$ pyruvate, $2 \mathrm{mM}$ glutamine, $50 \mu \mathrm{g} / \mathrm{ml}$ streptomycin and 50 units/ $\mathrm{ml}$ penicillin and induced to differentiate along the chondrogenic pathway by addition of $10^{-6} \mathrm{M}$ dexamethasone (Sigma). At day 40, $50 \mu \mathrm{g} / \mathrm{ml}$ ascorbic acid (Sigma) and $1 \mu \mathrm{M}$ thyroid hormone T3 (Sigma) were added to the differentiation medium.

\section{Cell growth kinetics}

C1 cells and transfectants were seeded at $10^{5}$ cells per $6 \mathrm{~cm}$ tissue-culture dish. Over the next 9 days, three separate dishes were harvested daily for each clone. Cells were removed by trypsin treatment, washed with PBS and counted with a hemocytometer. The number of cells at each point and for each clone was estimated by taking the mean of these three independent values. The different growth curves obtained were compared by SuperAnova statistic test.

\section{Gel electrophoresis and immunoblotting}

Protein extracts were prepared by washing cells in $4^{\circ} \mathrm{C}$ PBS, scraping into Laemmli sample buffer with $10 \mathrm{mM}$ dithiothreitol and then heating for $10 \mathrm{~min}$ at $95^{\circ} \mathrm{C}^{64}$ Aliquots were assayed for protein concentration using the Bio-rad protein assay kit (Bio-rad) and equal amounts of protein were loaded on an SDS- $15 \%$ polyacrylamide gel. Prestained low-range SDS-PAGE standards from Bio-Rad were used. As an internal control on HSP25 immunoblots, $100 \mathrm{ng}$ of purified HSP25 (SPP-710, StressGen, Canada) was run with the standards.

Proteins were electrotransferred onto Hybond-ECL nitrocellulose (Amersham). Equal loading of protein was verified by staining the membrane with Ponceau red. Immunoblots were performed as described in the ECL kit (Amersham Corp.). The general dilutions used were 1:5000 for first antibodies (anti-HSP25 SPA-800 from StressGen, anti-HSP84 PA3-012 from Affinity Bioreagent) and $1: 15000$ for peroxidase-conjugated secondary antibodies (anti-rabbit W4011 from Promega).

\section{Immunocytochemistry}

Cells for immunocytochemistry were grown on gelatin-coated sterile glass coverslips. At $50 \%$ confluence, cells were washed with $4{ }^{\circ} \mathrm{C}$ PBS and fixed in $4 \%$ paraformaldehyde for $15 \mathrm{~min}$ at room temperature. Coverslips were washed in PBS and stored at $4^{\circ} \mathrm{C}$ in PBS. Immunocytochemistry of coverlips was performed in a humid chamber. Coverslips were incubated in $0.1 \%$ Triton $X$ in PBS for $5 \mathrm{~min}$ to permeabilize the cells. Coverslips were blocked for $1 \mathrm{~h}$ in $3 \%$ BSA in PBS, then incubated with primary antibody $(1 / 100$ in $3 \%$ BSA/PBS) for $1 \mathrm{~h}$ : anti HSP25 (SPA801 from StessGen), anti
HSP84 (PA3-012 from Affinity Bioreagents), anti $\alpha$ B-crystallin (NCL6ABcrys from Novocastra-Tebu) or anti MKBP (gift from A Suzuki). The coverslips were washed three times in PBS and once in $3 \%$ BSA/PBS (5 min), then incubated with $1 / 400$ anti rabbit IgGСу3 (111-165-003 from Interchim), $10 \mu \mathrm{g} / \mathrm{ml}$ Hoechst 33342 (Sigma) and possibly $1 \mu \mathrm{g} / \mathrm{ml}$ FITC-phalloidin (Sigma), $30 \mathrm{~min}$ in the dark. After washing four times in PBS, coverslips were mounted on slides with Mowiol, dried overnight, and examined on a Leica DMRB microscope. Photographs were taken with KODAK 1600 film, and these were scanned and images assembled using Photoshop and Canvas.

\section{Image analysis of aggregate size distribution}

Images of aggregates were analyzed with $\mathrm{NIH}$-Image, in order to estimate the projection surface of the aggregates. From the projection surface of the aggregates, that more or less correspond to spherical masses, we deduced an estimated radius of the aggregates.

\section{Aggregate sections and immunohistochemistry}

For immunohistochemical analyses of cell aggregates, aggregates were collected, rinsed twice in PBS and fixed in $4 \%$ paraformaldehyde in PBS, $2 \mathrm{~h}$ at room temperature. They were embedded in $4 \%$ low melting point agarose (Appligen), prior to inclusion in Parasplast plus $^{*}$ (Sherwood Medical). Three $\mu \mathrm{m}$ sections cut on a Leica microtome were laid on treated slides (SuperFrost ${ }^{\star} /$ Plus) in $0.2 \%$ gelatin, dried at $37^{\circ} \mathrm{C}$ and stored at $4^{\circ} \mathrm{C}$. Before immunocytochemistry, the slides were cleared of paraplast in two Histo-clear (National Diagnostics) baths of $15 \mathrm{~min}$, then gradually rehydrated through an ethanol series and soaked in PBS for 5 min. Immunocytochemistry was performed in a humid chamber. Free aldehydes were saturated with $50 \mathrm{mM} \mathrm{NH}_{4} \mathrm{Cl}$ in PBS for $30 \mathrm{~min}$. Sections were submerged for $30 \mathrm{~min}$ in a blocking solution (3\% BSA in PBS), containing $0.5 \%$ Triton $\mathrm{X}-100$ for permeabilization, and $0.3 \% \mathrm{H}_{2} \mathrm{O}_{2}$ as substrate to block endogenous peroxidase activity of the tissues. The slides were washed three times $10 \mathrm{~min}$ in $3 \% \mathrm{BSA}, 0.1 \%$ Triton $\mathrm{X}$ in PBS, then incubated with 1/100 anti collagen II (from Rockland) in 3\% BSA, $0.1 \%$ Triton $X$ in PBS for $1 \mathrm{~h}$. After washing three times in $3 \% \mathrm{BSA}$, $0.1 \%$ Triton $X$ in PBS, slides were incubated with $1 / 100$ anti rabbit IgG-peroxidase in 3\% BSA, $0.1 \%$ Triton $X$ in PBS for $30 \mathrm{~min}$. Peroxidase activity was revealed using $0.03 \%$ diaminobenzidine tetrahydrochloride (Sigma), $0.005 \% \mathrm{H}_{2} \mathrm{O}_{2}$ in $0.1 \mathrm{M}$ Tris- $\mathrm{HCl}(\mathrm{pH} 7.6)$. The reaction was stopped in distilled water and the sections mounted in Mowiol. Observations were made on a Leica DMRB microscope. Photographs were taken with Kodak 64T film, scanned and images assembled as previously.

\section{RNA extraction and Northern-blot analyses}

Total RNA was extracted from cells and aggregates using the RNAplus kit from Quantum Bioprobe. Northern-blots were prepared with $20 \mu \mathrm{g}$ of RNA resolved on $1 \%$ agarose gels and transferred to Hybond- $\mathrm{N}^{+}$membranes (Amersham). Double stranded DNA probes were labeled by random-priming with the Megaprime kit (Amersham) using $\left(\alpha^{32} \mathrm{P}\right) \mathrm{dATP}$, while oligonucleotides were labeled by $\left(\gamma^{32} \mathrm{P}\right)$ ATP using T4 polynucleotide kinase. Hybridizations were carried out at $65^{\circ} \mathrm{C}$ for at least $15 \mathrm{~h}$ for double stranded DNA probes, while for oligonucleotides the temperature was gradually decreased until $30^{\circ} \mathrm{C}$ over $15 \mathrm{~h}$ after $30 \mathrm{~min}$ at $65^{\circ} \mathrm{C}$. Washes were performed at $40^{\circ} \mathrm{C}$, first with $2 \times$ SSC, $0.1 \%$ SDS $(2 \times 15 \mathrm{~min})$, then with $0.2 \times$ SSC, $0.1 \%$ SDS $(2 \times 15 \mathrm{~min})$. The membrane was exposed to $X-\mathrm{OMAT}^{\mathrm{TM}}$ film (Kodak). 


\section{Measurement of reduced glutathione (GSH) level}

Cells and aggregates at different stages were harvested and rinsed with PBS. $90 \%$ of each sample was analyzed for glutathione content ${ }^{65}$ and the remaining $10 \%$ was used to measure protein concentration. ${ }^{66}$

\section{Acknowledgements}

We are grateful to Dr. A-P Arrigo (Lyon, France) for providing the HSP25 containing plasmid used in this study. We thank Dr. E Vuorio for allowing us to use the Col I and Col II. Dr. A Suzuki and Dr. I Rubin for the kind gifts of anti MKBP antibodies and hygromycin resistant pKJ23 plasmid, respectively and Dr. S Davidson for critical correction of this manuscript. This work was supported by grants from ARC (Association pour la recherche sur le cancer) no 9840 and no 5939 and from AFM (Association française contre les myopathies) MNM 1999. O Duverger was supported by a grant from the Ministère de l'Education Nationale, de la Recherche et de la Technologie.

\section{References}

1. Hickey E, Brandon SE, Potter R, Stein G, Stein J and Weber LA (1986) Sequence and organization of genes encoding the human $27 \mathrm{kDa}$ heat shock protein [published erratum appears in Nucleic Acids Res 1986 Oct 24;14(20):8230]. Nucleic Acids Res. 14: 4127-4145

2. Jakob U, Gaestel M, Engel Kand Buchner J (1993) Small heat shock proteins are molecular chaperones. J. Biol. Chem. 268: 1517-1520

3. Gernold M, Knauf U, Gaestel M, Stahl J and Kloetzel PM (1993) Development and tissue-specific distribution of mouse small heat shock protein hsp25. Dev. Genet. 14: 103-111

4. Klemenz R, Andres AC, Frohli E, Schafer R and Aoyama A (1993) Expression of the murine small heat shock proteins hsp 25 and alpha B crystallin in the absence of stress. J. Cell. Biol. 120: 639-645

5. van de Klundert FA, Gijsen ML, van den IPR, Snoeckx LH and de Jong WW (1998) alpha B-crystallin and hsp25 in neonatal cardiac cellsdifferences in cellular localization under stress conditions. Eur. J. Cell. Biol. 75: $38-45$

6. Morange M, Favet N, Loones MT, Manuel M, Mezger V, Michel E, Rallu M and Sage J. (1998) Heat-shock genes and development. Ann. N. Y. Acad. Sci. 851: $117-122$

7. Morange M. (1999) Functions in development. In: Bukau B, editor. Molecular Chaperones and folding catalysts: Regulation, cellular Function and Mechanisms. Amsterdam: Harwood Academic Publishers; p. 163-176

8. Davidson SM and Morange M (2000) Hsp25 and the p38 MAPK pathway are involved in differentiation of cardiomyocytes. Dev. Biol. 218: 146-160

9. Loones MT and Morange M (1998) Hsp and chaperone distribution during endochondral bone development in mouse embryo. Cell. Stress Chaperones 3 : 237-244

10. Loones MT, Rallu M, Mezger V and Morange M (1997) HSP gene expression and HSF2 in mouse development. Cell. Mol. Life Sci. 53: 179-190

11. Loones M-T, Chang $Y$ and Morange $M(2000)$ The distribution of heat shock proteins in the nervous system of the unstressed mouse embryo suggests a role in neuronal and non-neuronal differentiation. Cell. Stress Chaperones 5: 291 305

12. Lavoie JN, Gingras-Breton G, Tanguay RM and Landry J (1993) Induction of Chinese hamster HSP27 gene expression in mouse cells confers resistance to heat shock. HSP27 stabilization of the microfilament organization. J. Biol. Chem. 268: $3420-3429$

13. Miron T, Wilchek M and Geiger B (1988) Characterization of an inhibitor of actin polymerization in vinculin-rich fraction of turkey gizzard smooth muscle. Eur. J. Biochem. 178: 543-553

14. Benndorf R, Hayess K, Ryazantsev S, Wieske M, Behlke J and Lutsch G (1994) Phosphorylation and supramolecular organization of murine small heat shock protein HSP25 abolish its actin polymerization-inhibiting activity. J. Biol. Chem. 269: $20780-20784$
15. Lavoie JN, Hickey E, Weber LA and Landry J (1993) Modulation of actin microfilament dynamics and fluid phase pinocytosis by phosphorylation of heat shock protein 27. J. Biol. Chem. 268: 24210-24214

16. Lavoie JN, Lambert H, Hickey E, Weber LA and Landry J (1995) Modulation of cellular thermoresistance and actin filament stability accompanies phosphorylation-induced changes in the oligomeric structure of heat shock protein 27. Mol. Cell. Biol. 15: 505-516

17. Guay J, Lambert H, Gingras-Breton G, Lavoie JN, Huot J and Landry J (1997) Regulation of actin filament dynamics by p38 map kinase-mediated phosphorylation of heat shock protein 27. J. Cell. Sci. 110: 357-368

18. Schneider GB, Hamano $\mathrm{H}$ and Cooper LF (1998) In vivo evaluation of hsp27 as an inhibitor of actin polymerization: hsp27 limits actin stress fiber and focal adhesion formation after heat shock. J. Cell. Physiol. 177: 575-584

19. Schafer C, Ross SE, Bragado MJ, Groblewski GE, Ernst SA and Williams JA (1998) A role for the p38 mitogen-activated protein kinase/Hsp 27 pathway in cholecystokinin-induced changes in the actin cytoskeleton in rat pancreatic acini. J. Biol. Chem. 273: 24173-24180

20. Rousseau S, Houle F, Landry J and Huot J (1997) p38 MAP kinase activation by vascular endothelial growth factor mediates actin reorganization and cell migration in human endothelial cells. Oncogene 15: 2169-2177

21. Liang P and MacRae TH (1997) Molecular chaperones and the cytoskeleton. J. Cell. Sci. 110: 1431-1440

22. Perng MD, Cairns $L$, van den IP, Prescott $A$, Hutcheson $A M$ and Quinlan RA (1999) Intermediate filament interactions can be altered by HSP27 and alphaBcrystallin. J. Cell. Sci. 112: 2099-2112

23. van den IJssel P, Norman DG and Quinlan RA (1999) Molecular chaperones: small heat shock proteins in the limelight. Curr. Biol. 9: R103-R105

24. Mairesse N, Horman S, Mosselmans R and Galand P (1996) Antisense inhibition of the $27 \mathrm{kDa}$ heat shock protein production affects growth rate and cytoskeletal organization in MCF-7 cells. Cell. Biol. Int. 20: 205-212

25. Rondeaux P, Horman S, Galand P and Mairesse N (1997) Effects of antisense hsp27 gene expression in osteosarcoma cells [letter]. In Vitro. Cell. Dev. Biol. Anim. 33: 655-658

26. Horman S, Fokan D, Mosselmans R, Mairesse N and Galand P (1999) Anti-sense inhibition of small-heat-shock-protein (HSP27) expression in MCF-7 mammarycarcinoma cells induces their spontaneous acquisition of a secretory phenotype. Int. J. Cancer 82: 574-582

27. Mehlen P, Mehlen A, Godet J and Arrigo AP (1997) hsp27 as a switch between differentiation and apoptosis in murine embryonic stem cells. J. Biol. Chem. 272: $31657-31665$

28. Mehlen P, Coronas V, Ljubic-Thibal V, Ducasse C, Granger L, Jourdan F and Arrigo AP. (1999) Small stress protein Hsp27 accumulation during dopaminemediated differentiation of rat olfactory neurons counteracts apoptosis. Cell. Death Differ. 6: 227-233

29. Preville X, Salvemini F, Giraud S, Chaufour S, Paul C, Stepien G, Ursini MV and Arrigo AP. (1999) Mammalian small stress proteins protect against oxidative stress through their ability to increase glucose-6-phosphate dehydrogenase activity and by maintaining optimal cellular detoxifying machinery. Exp. Cell. Res. 247: 61-78

30. Arrigo AP (1998) Small stress proteins: chaperones that act as regulators of intracellular redox state and programmed cell death. Biol. Chem. 379: 19-26

31. Kellermann O, Buc-Caron MH, Marie PJ, Lamblin D and Jacob F (1990) An immortalized osteogenic cell line derived from mouse teratocarcinoma is able to mineralize in vivo and in vitro. J. Cell. Biol. 110: 123-132

32. Poliard A, Lamblin D, Marie PJ, Buc-Caron MH and Kellermann O (1993) Commitment of the teratocarcinoma-derived mesodermal clone $\mathrm{C} 1$ towards terminal osteogenic differentiation. J. Cell. Sci. 106: 503-511

33. Poliard A, Nifuji A, Lamblin D, Plee E, Forest C and Kellermann O (1995) Controlled conversion of an immortalized mesodermal progenitor cell towards osteogenic, chondrogenic, or adipogenic pathways. J. Cell. Biol. 130: 14611472

34. Gaestel M, Gross B, Benndorf R, Strauss M, Schunk WH, Kraft R, Otto A, Bohm $\mathrm{H}$, Stahl J, Brabsch $\mathrm{H}$, et al. (1989) Molecular cloning, sequencing and expression in Escherichia coli of the 25-kDa growth-related protein of Ehrlich ascites tumor and its homology to mammalian stress proteins. Eur. J. Biochem. 179: $209-213$

35. Wakayama T and Iseki S (1999) Specific expression of the mRNA for $25 \mathrm{kDA}$ heat-shock protein in the spermatocytes of mouse seminiferous tubules. Anat. Embryol. (Berl.) 199: 419-425 
36. Suzuki A, Sugiyama Y, Hayashi Y, Nyu-i N, Yoshida M and Nonaka I, Ishiura S, Arahata K and Ohno S (1998) MKBP, a novel member of the small heat shock protein family, binds and activates the myotonic dystrophy protein kinase. J. Cell. Biol. 140: 1113-1124

37. Oesterreich S, Weng CN, Quu M, Hilsenbeck SG, Osborne CK and Fuqua SA (1993) The small heat shock protein hsp27 is correlated with growth and drug resistance in human breast cancer cell lines. Cancer Res. 53: 4443-4448

38. Kosher RA, KulykWM and Gay SW (1986) Collagen gene expression during limb cartilage differentiation. J. Cell. Biol. 102: 1151-1156

39. Wilkinson JM and Pollard I (1993) Immunohistochemical localisation of the $25 \mathrm{kDa}$ heat shock protein in unstressed rats: possible functional implications. Anat. Rec. 237: 453-457

40. Shakoori AR, Oberdorf AM, Owen TA, Weber LA, Hickey E, Stein JL, Lian JB and Stein GS (1992) Expression of heat shock genes during differentiation of mammalian osteoblasts and promyelocytic leukemia cells. J. Cell. Biochem. 48: $277-287$

41. Spector NL, Hardy L, Ryan C, Miller Jr. WH, Humes JL, Nadler LM and Luedke E (1995) 28-kDa mammalian heat shock protein, a novel substrate of a growth regulatory protease involved in differentiation of human leukemia cells. J. Biol. Chem. 270: 1003-1006

42. Stahl J, Wobus AM, Ihrig S, Lutsch G and Bielka H (1992) The small heat shock protein hsp25 is accumulated in $\mathrm{P} 19$ embryonal carcinoma cells and embryonic stem cells of line BLC6 during differentiation. Differentiation 51: 33-37

43. Piotrowicz RS, Hickey E and Levin EG (1998) Heat shock protein $27 \mathrm{kDa}$ expression and phosphorylation regulates endothelial cell migration. FASEB. J. 12: $1481-1490$

44. Rorth P, Szabo K, Bailey A, Laverty T, Rehm J, Rubin GM, Weigmann K, Milan M, Benes V, Ansorge W and Cohen SM (1998) Systematic gain-of-function genetics in Drosophila. Development 125: 1049-1057

45. Kato K, Goto S, Inaguma Y, Hasegawa K, Morishita R and Asano T (1994) Purification and characterization of a $20-\mathrm{kDa}$ protein that is highly homologous to alpha B crystallin. J. Biol. Chem. 269: 15302-15309

46. Boelens WC, Van Boekel MA and De Jong WW (1998) HspB3, the most deviating of the six known human small heat shock proteins. Biochim. Biophys. Acta 1388: $513-516$

47. Krief S, Faivre JF, RobertP, Le Douarin B, Brument-Larignon N, Lefrere I, Bouzyk MM, Anderson KM, Greller LD, Tobin FL, Souchet M and Bril A (1999) Identification and characterization of cvHsp. A novel human small stress protein selectively expressed in cardiovascular and insulin-sensitive tissues. J. Biol. Chem. 274: 36592-36600

48. Richards EH, Hickey E, Weber L and Master JR (1996) Effect of overexpression of the small heat shock protein HSP27 on the heat and drug sensitivities of human testis tumor cells. Cancer Res. 56: 2446-2451

49. Landry J, Chretien P, Lambert H, Hickey E and Weber LA (1989) Heat shock resistance conferred by expression of the human HSP27 gene in rodent cells. J. Cell. Biol. 109: 7-15

50. Huot J, Roy G, Lambert H, Chretien P and Landry J (1991) Increased survival after treatments with anticancer agents of Chinese hamster cells expressing the human $\mathrm{Mr}$ 27,000 heat shock protein. Cancer Res. 51: 5245-5252

51. Mehlen P and Arrigo AP (1994) The serum-induced phosphorylation of mammalian hsp27 correlates with changes in its intracellular localization and levels of oligomerization. Eur. J. Biochem. 221: 327-334
52. Arrigo AP, Suhan JP and Welch WJ (1988) Dynamic changes in the structure and intracellular locale of the mammalian low-molecular-weight heat shock protein. Mol. Cell. Biol. 8: 5059-5071

53. Mehlen P, Hickey E, Weber LA and Arrigo AP (1997) Large unphosphorylated aggregates as the active form of hsp27 which controls intracellular reactive oxygen species and glutathione levels and generates a protection against TNFalpha in NIH-3T3-ras cells. Biochem. Biophys. Res. Commun. 241: 187 192

54. Mehlen P, Schulze-OsthoffKand Arrigo AP (1996) Small stress proteins as novel regulators of apoptosis. Heat shock protein 27 blocks Fas/APO-1- and staurosporine-induced cell death. J. Biol. Chem. 271: 16510-16514

55. Mehlen P, Kretz-Remy C, Preville X and Arrigo AP (1996) Human hsp27, Drosophila hsp27 and human alphaB-crystallin expression-mediated increase in glutathione is essential for the protective activity of these proteins against TNFalpha-induced cell death. EMBO J. 15: 2695-2706

56. Mehlen P, Preville X, Chareyron P, Briolay J, Klemenz R and Arrigo AP (1995) Constitutive expression of human hsp27, Drosophila hsp27, or human alpha Bcrystallin confers resistance to TNF-and oxidative stress-induced cytotoxicity in stably transfected murine L929 fibroblasts. J. Immunol. 154: 363-374

57. Oberlender SA and Tuan RS (1994) Expression and functional involvement of $\mathrm{N}$ cadherin in embryonic limb chondrogenesis. Development 120: 177-187

58. Tavella S, Raffo P, Tacchetti C, Cancedda R and Castagnola P (1994) N-CAM and $\mathrm{N}$-cadherin expression during in vitro chondrogenesis. Exp. Cell. Res. 215: $354-362$

59. Tavella S, Bellese G, Castagnola P, Martin I, Piccini D, Doliana R, Colombatti A, Cancedda R and Tacchetti C (1997) Regulated expression of fibronectin, laminin and related integrin receptors during the early chondrocyte differentiation. J. Cell. Sci. 110: 2261-2270

60. Chimal-Monroy J and Diaz de Leon L (1999) Expression of N-cadherin, N-CAM, fibronectin and tenascin is stimulated by TGF-betal, beta2, beta3 and beta5 during the formation of precartilage condensations. Int. J. Dev. Biol. 43: 59-67

61. Pavalko FM and Otey CA (1994) Role of adhesion molecule cytoplasmic domains in mediating interactions with the cytoskeleton. Proc. Soc. Exp. Biol. Med. 205: 282-293

62. Ciocca DR, Oesterreich S, Chamness GC, McGuire WL and Fuqua SA (1993) Biological and clinical implications of heat shock protein 27,000 (Hsp27): a review. J. Natl. Cancer Inst. 85: 1558-1570

63. KnaufU, JakobU, EngelK, Buchner Jand Gaestel M (1994) Stress- and mitogeninduced phosphorylation of the small heat shock protein Hsp25 by MAPKAP kinase 2 is not essential for chaperone properties and cellular thermoresistance. EMBO J. 13: $54-60$

64. Laemmli UK (1970) Cleavage of structural proteins during the assembly of the head of bacteriophage T4. Nature 227: 680-685

65. Saville B (1958) A scheme for the colorimetric determination of microgram amounts of thiols. Analyst 83: $670-672$

66. Bradford MM (1976) A rapid and sensitive method for the quantitation of microgram quantities of protein utilizing the principle of protein-dye binding. Anal. Biochem. 72: 248-254 